\title{
CPI Welcomes Maria Wallis and Cecille DePass’' Special Issue
}

In "Still I rise: a tribute to Maya Angelou", Maria Wallis and Cecille DePass, co-editors, have joined forces to create a special issue in which carefully selected articles, narratives, artwork, poetry and music, all play integral roles. In doing so, the special issue highlights a wide range of ways of singing songs of resistance.

From its inception, CPI has established a reputation for publishing academic work which encourages its readers to see with fresh eyes, the often 'taken for granted' socio-economic, political and cultural environments in which we live. The Fall 2016, CPI Special Issue continues this tradition. As importantly, it continues to tap into contributions by individuals from social sciences, education, humanities and the arts who research, write and produce work which complement the issue's chosen theme. At the same time, this issue demonstrates even more fully, some potential, inherent in publishing an online academic journal.

CPI continues to rely on the generosity and willingness of all contributors to make another CPI dream, a visible and audible reality. CPI thanks all contributors for their tremendous efforts to co-create a special issue which pays tribute to the iconic African American woman, Maya Angelou.

CPI thanks the peer reviewers; the individuals consulted (nationally and internationally) for excellent referrals and contacts; the members of the CPI production team, Dr. Peggy Dobson, Kendra Grabatin, and Tania Guerrero, for ensuring that the journal maintains its international reputation for excellence, creativity and meaningful innovations.

\section{Large symbolic CPI bouquets for literary contributions, publications, research projects and awards in the field:}

CPI acknowledges the following thinkers and community advocates for their selfless contributions to making a world in which equity, fairness and justice are respected and lived:

Yvonne Brown has been conducting archival research in England and Jamaica for a second book. In Jamaica (summer 2016), she presented a paper from her current research for a joint conference, organized by the University of the West Indies, Mona, Jamaica and the Harriet Tubman Institute, York University, Ontario.

In October 2016, Cyril Dabydeen (author of the Summer CPI Special Issue), participated in two major, invitational, international conferences at the Senate House, University of London, England. At the first conference, organized by scholars from France, UK, US, and Canada, Dabydeen was the only delegate invited from Canada. He presented some of his work and spoke about his childhood on a Guyanese sugar plantation. At the second conference, still at the Senate House, he presented more of his work, for the "Celebration of Guyana in Poetry and Music." In summer 2016, the Guyana Cultural Association, New York, gave Cyril Dabydeen an Exemplary Award for his distinguished contributions to literature. 
As importantly as, travelling extensively to present research at several national and international conferences (including the World Congress of Comparative Education Societies [WCCES], Beijing, China), in 2016, Shibao Guo and Yan Guo edited and published two books on China: firstly, "Spotlight on China: Chinese education in the globalized world", Rotterdam: Sense Publishers; secondly, "Spotlight on China: Changes in education under China's market economy", Rotterdam: Sense Publishers. In 2016, Shibao Guo edited: "Working, learning and transnational migration: Opportunities, challenges and debates", London: Routledge. The year before, Shibao Guo and Lloyd Wong (2015), edited: "Revisiting multiculturalism in Canada: Theories, policies and debates", Rotterdam: Sense Publishers.

Kim Huynh has exhibited her art in three public exhibitions at the University of Calgary (2016): firstly, a Solo Art Installation: "If I Had a Hammer"; secondly, Huynh included photographs from "If I Had a Hammer" for inclusion in the artists' exhibition, Comparative and International Educational Society of Canada (CIESC), Preconference, May 27, 2016 which ran for the entire SSHRC Congress; and thirdly, Fall 2016, an Art Installation: "Demulsify", a two-part work which continues to portray such central social justice themes as, contrasts between 'the wealthy few' and 'the poverty of the many in Canada', and issues of consumerism. The third installation is intricately layered and as complex as a Chinese puzzle.

Enid Lee, in summer 2016, in her inimitable manner, continued to win the minds and hearts of educators to be encouraged to take action \& implement teaching strategies, deliberately designed to foster equity. Enid Lee was in Washington DC, as an invited fellow, with the Teaching for Change Organization and the Washington Teachers Union. While there, she participated in several national conferences and meetings. Enid Lee presented one of the major seminars at a national conference for educational leaders, in Washington DC. The conference was associated with the opening of the new Smithsonian National Museum of African American History and Culture. As importantly, from her keynote lectures, at least one video, available online, is to be produced. Enid Lee's edited book with Maro Okazawa-Rey \& Deborah Menkart, Beyond Heroes and Holidays: A Practical Guide, K-12: Multicultural, Anti-Racist Education and Staff Development, Washington, DC: Teaching for Change Organization, is to be republished.

During the year, Pam Mordecai, Kitchener, Waterloo travelled to the Caribbean and across Canada (to Jamaica, the Maritimes, Winnipeg, and Vancouver), as well as, to several cities in Ontario in order to present by invitation, at several university conferences, literary meetings and public events. She has showcased her work, with concentration given to her two recent books: Red Jackets (2015), Toronto: TAP Books, shortlisted, Rogers Writers' Trust Fiction Prize, and De Book of Mary: A Performance Poem (2015), Toronto: Mawenzi House.

CPI reminds its Editorial Board members, readers and contributors to share information regarding: research, publications and major accomplishments. Information to be published annually. 


\section{CPI Special Issues to be produced in the next 2 to 3 years:}

Summer 2017: Jennifer Eiserman and some artists from the University of Calgary, Visual Arts Department plan to publish a special issue to be based on the public exhibition and interactive panel which launched the Preconference, Comparative and International Education Society of Canada (CIESC). The Preconference, linking town and gown, was deliberately created for CIESC's Annual Conference, affiliated with the larger Canadian Society for the Study of Education (CSSE) Conference and the SSHRC Congress, University of Calgary, Spring 2016.

Fall 2017: Kathleen Sitter, Assistant Professor at Memorial University will produce a special issue: "Creating our Canvas: Blending Visual Art and Storytelling into the Curriculum Palette". The special issue, with strong conceptual and theoretical frameworks is to be developed from a participatory research project with some Social Welfare students at Memorial University.

Summer 2018: Carol Lee, to produce a special issue of original poetry: "No Return". Work has been submitted to CPI, Fall 2016. Preliminary review completed and work very favourably reviewed.

Fall 2018: Cecille DePass and selected contributors to produce a special issue, based on: 'Another Tea at the Empress: Contesting Institutional Colonial Agendas in the formal/nonformal curriculums, CIESC, Preconference, May 28, 2016. (A follow-up to the Summer 2015, CPI Special Issue).

Summer or Fall 2019: Carol Campbell and a few senior professors, at the Edna Manley College for the Visual and Performing Arts, plan to create a special issue to showcase the state of contemporary arts in Jamaica. The special issue will be a tribute to Edna Manley who dedicated her life though her sculpture, literary and political activities to implicitly and explicitly, influence, build and found significant shifts in arts, publishing, \& literary worlds in Jamaica and the Caribbean.

\section{CPI welcomes new board members:}

Formally educated in classical, contemporary and folk music in Colombia and Canada, Carlos A. Arcila, independent scholar and musician, has conducted research since the late 1990s exploring and documenting links between oral traditions and music of the Southwest Pacific Coast of Colombia (this issue). In 2001, Carlos Arcila won a National Award, for the musical composition which paid tribute "to his dear friend who had introduced him to the rich and beautiful oral traditional music of the Colombian Pacific coast". In Colombia, Carlos Arcila was a well known and well loved musician, teacher, performer and conductor. In the latter roles, e.g. he was a conductor with the Symphonic Band at the Juan N. Corpas University, Bogota, and a teacher at the same institution.

Kim Huynh, University of Calgary, Alberta, is a well established and highly respected member of the academy. Some of her work is included in this issue.

Kathleen Sitter, Memorial University, Newfoundland, is a film maker and academic, known in Canada for her work combining participatory action research and visual media. Using photography, digital storytelling, and video, Sitter has had exhibitions and screenings of her Cultural and Pedagogical Inquiry, Fall 2016, 8(2), pp. i-iv ISSN 1916-3460 @ 2016 University of Alberta http://ejournals.library.ualberta.ca/index.php/cpi/index 
research across Canada. Sitter's research in critical disability theory focuses on ethics and distribution as it relates to inclusive, accessible, and collaborative forms of research methodologies. Her dissertation work about disability and sexual rights was awarded the 2013 Outstanding Dissertation Award from the Disability Studies in Education SIG of the American Education Research Association. Sitter's more research has also been funded by SSHRC and CIHR.

\section{Departures and Arrivals:}

Unfortunately, Mathew Zachariah, Professor Emeritus, Education, University of Calgary, passed away in Calgary, October 25, 2016. Dr. Zachariah was a leader in the fields of comparative and international education, social justice, development education and multiculturalism. He played instrumental roles in a range of academic and community organizations, including: (i) several comparative education societies such as Comparative and International Education Society (USA) and CIESC (Canada); (ii) the Canadian Commission-UNESCO; (iii) the Shastri Institute, University of Calgary; (iv) Alberta Teacher's Association's, Global Education Project; (v) Arusha Centre (Calgary), and (vi) the Canadian Race Relations Foundation. Mathew Zachariah worked with Paulo Freire (Brazil), and invited him to be the leader for a U of C conference in the early 1980s. Zachariah published innumerable articles and several books, including a seminal work which compared the work of Paul Freire with M. Ghandi: "Revolution through Reform". He was a prodigious researcher, writer and author, presented and organized countless academic and community conferences, as recently as 2016 . He will be sorely missed. CPI wishes to extend deepest sympathy to the Zachariah family. Dr. Mathew Zachariah's Celebration of Life, Saint James Anglican Church, Calgary, October 28, 2016 can be seen at http://www.yoursideit.com/MZ_Funeral.mp4

Cree Elder Doreen Spence, Calgary, is the recipient of an Inspire Award: Celebrating Indigenous Achievements (2017). Inspire is the largest NGO which funds Indigenous education in Canada. Spence has worked unstintingly on behalf of indigenous people all her life. She is a standing member of the UN Commission for Aboriginal peoples, has been on a UN international mission to an East African country, has been a former University of Calgary, Senator, and was one of the 100 women in the world nominated for a collective UN peace prize, some years ago. Congratulations Elder Spence.

Finally, CPI thanks the University of Alberta Libraries, for hosting the journal as an Open Access academic journal. This special issue, in particular, includes contributions by a number of self-employed academics, artists, writers, poets and musicians. CPI requests that any future publication or exhibition of the specific work, kindly acknowledges prior publication in CPI.

In the future, CPI wishes to encourage more contributions from/by the south in literature, the visual and performing arts.

Warm wishes for the northern hemisphere winter and the southern hemisphere summer.

Sincerely,

Cecille DePass and Ali A. Abdi (Editors)

Cultural and Pedagogical Inquiry, Fall 2016, 8(2), pp. i-iv

ISSN 1916-3460 @ 2016 University of Alberta

http://ejournals.library.ualberta.ca/index.php/cpi/index 